\title{
The Implementation of Task-based Language Teaching Approach in Vocational College English in China
}

\author{
Qu Renxiong \\ sichuan information Technology College 375648575@qq.com 628017
}

\begin{abstract}
Key words: task-based language teaching; English teaching in higher vocational college; tasks; teaching methods
\end{abstract}

Abstract. Task-based Language Teaching refers to a kind of language teaching model, in which students learn language through accomplishing a series of tasks under the instructions of teachers. This kind of teaching model takes group/ pair learning as the basic way. The members of group fulfill the tasks assigned by the teachers individually or cooperatively through brainstorming, negotiating or discussing with each other. The core of task-based language teaching aims at asking teachers and students to imitate the various activities or tasks which can be undertaken by using languages in present schools or in the future society, which combines language teaching with the practical language use in the future lives of learners.

Under the guidance of such theories as 3A (awareness, autonomy, authenticity) theory, group dynamics theory, the second language acquisition theory and social constructivist theory, the thesis borrows the latest findings on task-based language teaching (regardless of foreign or domestic), abides by the principles and demands of the Basic Demands on the Vocational College English Teaching (Ministry of State Education, 2000), connects with the actual conditions on the domestic vocational college English teaching and the author's specific teaching practice, tries to make some discussions and researches on how to apply the new teaching model of task-based language teaching in vocational college English teaching, in both theoretical and practical perspectives.

The thesis firstly analyzes the necessities and the feasibilities of applying the new model of task-based language teaching in higher vocational college English teaching, then makes some practical researchers and emphasizes on the teaching of four language basic skills, i.e. listening, speaking, reading, writing, and on that of language knowledge. The thesis also claims in short that vocational college English teaching with task-based approach should contain the teaching of culture awareness. At last, the thesis suggests that formative assessment should also be advocated in vocational college English teaching and formative assessment should be the one of main assessment forms besides summative assessment. Task-based language teaching creates the conditions for carrying out formative assessment and it can shows its advantages only with the combination of summative assessment and formative assessment.

Without doubt, it has many advantages to employ the latest model of task-based language teaching in higher vocational college English teaching. This teaching model can make students learn and practice English in the procedure of fulfilling tasks, which can not only cause learners to experience the feeling of successes, arouse their study interests, create a relax, natural and authentic language environment, enhance their language knowledge and abilities of language use, but also train learners' abilities of thinking in English and cultivate their such good virtues as activeness, cooperation, interactiveness.

\section{Introduction}

With the publication of Threshold Level English in a European Unit /Credit System for Modern language Learning by Adults (Van Ek, 1975) and Threshold Level English for Modern Language Learning in schools (1976), it came to the times of communication, and communicative approach in language teaching became a kind of hot teaching method. In the 1980s, communicative approach in language teaching developed so much that task-based approach, the latest form of five ones deriving from communicative approach, came into being. From then on, a lot of educators and linguists have being made great efforts to task-based approach. In 1980s, British educators Prabhu 
undertook a so-called Bangalore Project in the southern India, which was supposed to be the first project to use tasks as the unit around which the course was organized. He put forward many types of tasks, and designed learning content as communicative tasks. Since Prabhu's experiment, many others have offered their ideas on using tasks in this way. All these works use tasks as their central component. So with the development of study on such tasks, the theory to task-based language teaching came into form at the beginning of 1990s. Jenny Willis's “A Framework for Task-based Learning (TBL)” (1996) provided guidance for classroom teachers to use a task-based learning approach in their classrooms. She set out to make the transition to a task-based learning as easy as possible, and gives a very comprehensive description of how to teach a task-based lesson. Actually, Willis offered instructions on operating dimension and put forward five principles when teaching tasks were carried out. Willis also aimed to include a focus on form in her approach to task-based learning. And Skehan (1991, 1998) advocated the language learning cognitive approach, which afforded one of the theories to task-based language teaching.

According to its advocators, task-based approach is an effective way to help students to improve their integrated language competence, especially the four basic language skills. It places emphasis on learning to communicate through purposeful interaction in the target language and aims at providing opportunities for learners to experiment with and explore both spoken and written language through tasks that are designed to engage learners in the authentic, practical and functional use of language for meaningful purposes. The use of tasks will also give a clear and purposeful context for the teaching and learning of grammar and other language features as well as skills.

Although it is just two decades since the Communicative Language Teaching (CLT) approach was introduced to the Chinese foreign language community, these twenty years have witnessed profound changes in foreign language teaching in China. As the latest development of CLT, task-based language teaching derived in 1982 (Lu Ziwen, 2003, p4), but it was in 1996 that task-based language teaching appeared firstly in Hong Kong. With the issue of New English Curriculum Standard in China in 2001, task-based approach has been advocated and adopted widely in primary and middle school.

So, a lot of Chinese researchers and educators such as Lu Ziwen, Gong Yafu, Luo Shaoxi, and Cheng Lin have being made their great contributions to task-based language teaching and a lot of achievements have been made since then. But unfortunately, task-based language teaching approach, the most modern and latest approach, has not been well-researched and put into practice in vocational school in China, as far as the author knows. As a result, students in vocational school, even after they graduate, cannot interact with each other even in everyday English. Teachers don't know how to teach effectively, either.

This thesis aims at the analysis and study of the necessity and feasibility, the concrete ways and the evaluation of employing task-based language teaching approach as well as some problems involved when teachers design task-based language teaching activities in vocational college English teaching in China.

\section{Part One The Necessities and Feasibilities for Task-based Language Teaching in Vocational College in China}

Task-based Language Teaching can provide learners opportunities to exposure themselves to a great deal of language input and output and authentic language use, which are just the essence and ideal model of language acquisition (Gong Yafu \& Luo Shaoxi, 2003). Task-based language teaching can also arouse learning motivation to the most extent. In task-based language teaching, to adapt kinds of tasks, learners can have opportunities to apply the language they have learnt and are learning extensively, and to learn to communicate with each other. In addition, to have task-based language teaching in vocational college English has the following reasons.

\section{The Present Situation of Vocational College English Teaching}

The author of this thesis ever made an investigation randomly on the methods of English teaching among 15 teachers who all came from various vocational schools. Eight of them said that they had never heard of such a method and seven of them had known about it but never employed 
such method in their teaching. Most of them said that English is no longer the main subject in vocational school because students needn't take part in NMET and the authority doesn't place teaching emphasis on it. As a result, the teachers have no chance to go out for further study for the latest teaching methods and even no chance to feel new teaching ideas. So it is very obvious that traditional grammar-translation teaching method still overwhelmingly occupies the post in vocational college English teaching.

Indeed, grammar-translation method has its own advantages. It became popular in the late $18^{\text {th }}$ century. At that time, the method was praised as active, simple, and effective. But in the final decades of the $19^{\text {th }}$ century grammar-translation was attacked as a cold and lifeless approach to language teaching, and it was blamed for the failure of language teaching. Grammar-translation lays little or no emphasis on the speaking of the second language or listening to second language speech. It is mainly a book-oriented method of working out and learning the grammatical system of the language. The teacher explains the grammar features and the technical grammatical terminology in the course book in his/her lesson. The learner is expected to study and memorize a particular rule and examples. Although the first language as a reference system is very important for the second language learner and it can play a certain part in language learning, the major defect of grammar-translation lies in the overemphasis on the language as a mass of rules and in the limitations of practice techniques that never emancipate the learner from the dominance of the first language. In addition, the task of memorization is heavy and difficult for learners and language facts are presented in an isolated way. Furthermore, it puts too much emphasis on reading and writing and neglects listening, speaking and culture awareness, viewing learning a foreign language as merely learning about the language.

Besides, traditional teaching only strengthens the importance of the teacher to students, especially stress laid on the teachers' authority to the students, and neglects that of the students and the students. In class the teacher would speak and speak from the beginning to the end without a stop. While the students don't know what the teacher says and feel tired of his/her teaching. The effects of the students were limited to the teacher's authoritative control. Teaching is guiding and facilitating learning, enabling the learner to learn, setting the condition for learning (Douglas Brown, 1983). For ages, teacher-centeredness is the main and traditional grammar-translation teaching in our country and duck-feeding teaching occupies the whole class. Whether a teacher prepares for his lessons carefully and he/ she lectures orderly or not are the main standards to assess his teaching. Therefore, a teacher spends massive time in lecturing. He cannot offer students enough chances to practice English. Students become the passive receivers of language. Such teaching model is not suitable to the ideas of language teaching and is no use improving the teaching and learning quality.

Firstly, such teaching model prevents students from improving their abilities and activeness of learning. In the whole class time, teachers occupy all time to lecture, while students can only listen and note and they hardly have the opportunities to engage in language activities and cannot have the sense of success. So it is very easy for students to lose their intrinsic motivation of learning.

Secondly, it's no use improving the abilities of expressing themselves in language. Krashen (1981) claims that the abilities to express themselves in language is decided by the learner's system of language acquisition and the properties to quicken the system is that learners must have chances to exposure to the massive comprehensible language input and absorb it fully. Krashen (1985) argues that the main function of foreign language class is to create the environment where the language input will be absorbed so that the language acquisition can occur. The class of teacher-centered only focuses on teaching language knowledge and it can hardly offer learners enough language input. Moreover, because such class only emphasizes the form and accuracy of language, it will cause learners to be nervous and anxious, which will prevent the language input from being absorbed.

Thirdly, the teaching model of ducking-feeding will disturb the communication between teaching and learning in this situation, teacher cannot have the feedback from learners and don't know what happened in the teaching. As a result, teacher cannot carry out his teaching with aim and purpose, which will affect the teaching efficiency without doubt. 
Due to the above reasons, students in vocational college just memorize some dead and isolated English words as well as grammar rules, and they cannot speak to and communicate with each other even in everyday English. Such 'mute' English will block their way to learn English.

\section{The Specific Characters of Students in Vocational College}

It is surprised that every student is eager to be an excellent English speaker but most of them don't like, even hate the English subject in vocational college. One of reasons is that they don't like the way of teaching English and English is too hard for them to learn it well and speaking pure and beautiful English fluently only can be an untouchable dream hidden in their heart. For ages of learning English, they address that they have learnt nothing except some dead and unhelpful words and grammar rules. Learning English is just to pass the final exam and to get necessary credit. They lose their hearts. To most of the students in our college, studying in our school absolutely is their last step in their lives. They absolutely want to learn the knowledge which will benefit them much in future. But what our English classes give them makes them very unsatisfied.

The students in our college are all from some senior schools or our own technical school and they have learnt English for at least six years. They have already learnt almost all English grammar rules, sentence structures and enough words, which are the base to implement tasks in English teaching. So the students in our college can accomplish tasks in English under the instruction of a teacher. They are able to undertake the brainstorming, collect and analysis the necessary materials and report the results in class. They have enough abilities to deal independently or cooperatively with the problems appearing in the whole procedure of fulfilling a task.

Another possibility for vocational college students to engage in the task-based language teaching is that they have no other exam pressure. Compared with in other kinds of schools, the author doesn't know whether implementing the task-based teaching is easier and more effective in vocational college, but it is a fact that both teachers and students have less pressure when engaging in task-based language teaching and learning in vocational school. They have no need to spend much time and energy in teaching endless language points such as words usage, grammar rules and the like. Both students and teachers will have more possibilities to learn English in a relax situation. They won't worry that they might miss in lecturing time a certain language point which is very likely to be checked in college entrance examination or that they might 'waste' too much time on what has nothing to do with the senior school or college entrance examination. The teachers in vocational school can more freely adjust their teaching process or plan according to the actual teaching designing and they needn't be in a hurry to finish a certain content or lesson, which is crucial for implementing task-based language teaching.

\section{The Demands of Society to Vocational College Students}

With the entry to WTO and the globalization of world economy, China comes to be emerged into the whole world in terms of economy. As a widely-used international language, English becomes a necessary quality that a modern person must have. People in 'global village' need to cooperate and communicate with each other. Such quality doesn't mean how many words a person only has, how familiar he is with grammar rules, but deal with the problems and interact and exchange the thoughts with the 'global citizens'.

The main task of vocational college is to cultivate technical workers or clerks with higher quality for firms and enterprises. Regardless of being secretaries, clerks, waiters or technical workers, they are likely to be in such situations where they may or must use English. Secretaries may deal with foreign correspondence and meet some foreign customers at airport; clerks in a travel agency may receive guests from all over the world; works in companies may operate some machines introduced from other countries and read some directions about controlling the machines; and the like. But most of them are unlikely to be specialists in English. They only need to learn necessary skills and new tricks for immediate use and some necessary knowledge for further improving themselves in future.

In addition, another perspective which has gained increasing prominence in language teaching is that of the student as a 'whole person'. In other words, language teaching is not just about teaching language, it is also about helping students to develop themselves as people, which is just the 
demand of the society to its citizens and the eventual aim of the whole education. In task-based language teaching and learning, students have a lot of chances to be invited to finish various kinds of tasks. In the processes, students can accompilsh tasks either individually or working with others. No matter which way is employed, student's integrated qualities can be enhanced greatly. In the future social lives, they can be an independent person and face any difficulties, and they can also build and develop good relationshish with his or her collegues.

\section{The Demands of the Curriculum and the Syllabus}

The Basic Demands on Vocational College English Teaching (Ministry of Education, 2000) addresses the destination of vocational college English teaching, i.e. to reinforce learners' basic language knowledge and skills, to focus on training practical competence of applying English to communicate with each other in life. The Basic Demands on Vocational College English Teaching also states that the education of vocational college cultivates higher and special workers for such fields as technology, manufacturing, management and service. So, the abilities of applying English must be laid on the more important position, especially for the ability of applying English to carry out some daily or foreign business activities. Again in The Basic Demands on Vocational College English Teaching, ' the general objective of vocational college English teaching must aim to the English activities that graduates will be faced by the foreign business in their future work.' Zhang Raoxue, the director of Higher Education Division of Ministry of Education, stresses that our education must connect the training with social demands. The English teaching in college must train the college students' abilities of applying English, focus on the competence of listening, speaking and dealing with practical affairs in real life. Zhang says we must change the idea that writing, reading and translation are more important and listening and speaking can be placed at the edge of English teaching. In addition, he says, the traditional teaching model also must be changed and some new ones should be explored and introduced into vocational college English teaching.

As a result, the Ministry of State is ready to innovate the college English teaching (Zhang Raoxue, 2004). The general objective of college English teaching must be reinforced. That is to say, college English teaching must cultivate the learners' integrated competence of applying English, especially that of listening and speaking so that the learners can exchange oral or written information in English effectively in their future work and social activities. The first is to change the teaching syllabus, moving the emphasis from on reading comprehension to on listening and speaking. The second to innovate the teaching model, from the passive model where a teacher talk and talk while students just listen and make notes to the active one where students can extend their personalities to study effectively under the instruction of a teacher. The third is to innovate the evaluation system. Regardless of in grading exam or in CET4 or CET6, the evaluation system of just judging grammar, reading and translation will be taken place by a new one that evaluates the students integrated language skills and enlarge the proportion of listening and speaking.

In any perspective, college English teaching is eager to pursuit a better teaching method and everybody in this field expects to find and employ a new and effective method to suits to the demands of society.

\section{Part Two The Theoretical Bases of Task-based Language Teaching}

Nowadays the task-based language teaching approach is bearing an honorable statue and regarded as a most overwhelming, popular and practical approach in teaching field, especially in primary and middle schools all over the world. One reason is that it has stable and scientific bases. Now in light of the theoretical bases of task-based language teaching, according to the nature of English teaching and the real teaching condition of vocational college English, the author tries to build the theoretical bases for task-based language teaching in vocational college.

\section{A Curriculum Idea}

van Lier (1996) put forward an idea to design curriculum, which was based on his ages of research and massive teaching practice. In the perspective of a learner, he integrated learning theory, course theory and teaching practice into 3A Curriculum Idea, i.e. awareness, autonomy and authenticity. In the perspective of the 3A Curriculum Idea, we can understand the theoretical base to 
task-based language teaching more evidently.

\begin{tabular}{|c|c|c|}
\hline & $\begin{array}{l}\text { Epistemology } \\
\text { (knowledge base) }\end{array}$ & $\begin{array}{l}\text { Axiology (ethical issues) } \\
\text { (values) }\end{array}$ \\
\hline Awareness & $\begin{array}{ll}- & \text { Focusing attention } \\
- & \text { Role of perception }\end{array}$ & $\begin{array}{l}\text { - Know what you are doing, } \\
\text { and why } \\
\text { - Conscious engagement } \\
\text { - Reflection }\end{array}$ \\
\hline Autonomy & $\begin{array}{ll}\text { - } & \text { Self-regulation } \\
\text { - } & \text { Motivation } \\
\text { - } & \text { Depth of processing }\end{array}$ & $\begin{array}{ll}- & \text { Responsibility } \\
\text { - } & \text { Accountability } \\
\text { - } & \text { Free choice } \\
\text { - } & \text { Democratic education } \\
\end{array}$ \\
\hline Authenticity & $\begin{array}{ll}\text { - } & \text { Language use in life } \\
\text { - } & \text { Relevance } \\
\text { - } & \text { Communication }\end{array}$ & $\begin{array}{ll}\text { - } & \text { Commitment to learning } \\
\text { - } & \text { Integrity } \\
\text { - } & \text { Respect }\end{array}$ \\
\hline
\end{tabular}

(van Lier: Interaction in the Language Curriculum)

van Lier argues that if a teacher presents new language points to students, one of his main tasks is to connect what he is teaching (regardless of topic, grammar or vocabulary) with the knowledge structure or life experience that learners had, and also to make learners sure what is the purpose to learn them and what they can do with them. Only learners have such 'awareness' and know what and why they are doing like this, can they concentrate on what they are learning. When a teacher instructs students to do activities, he should have students understand the purpose, if so, students can actively take part in such activities and accomplish kinds of tasks assigned by a teacher.

Autonomy is concerned with student's self-regulation, motivation, responsibility and the sense of duty. The two more important aspects of autonomy are choice and sense of responsibility. If learners receive knowledge passively, they cannot care what they are learning and will learn, and they also cannot concentrate on them. So to design tasks requires considering the needs of learners. The presenting and designing of tasks should not only be the idea and the thought of teacher's, they also can be the demand and the thought of learners'. Teacher should offer learners the rights of choosing tasks freely and of choosing the way of accomplishing tasks.

van Lier argues that authenticity refers to not only the relevance between the being used materials and real life but also people's real action. He addresses that people's reaction is driven by their intrinsic motivation. In language activities, learners do what they want to, express what they think truly. So, van Lier emphasizes greatly the authenticity of situation, the authenticity of purpose and the authenticity of communication in language teaching.

\section{Social Constructivist Teaching and Learning Theory}

Constructivist viewpoint of teaching and learning is an active constructive process. Learners are not passive to accept the external information, but active to choose the external information according to the former cognitive structure in order to construct the meaning of the present situation. The process of the construction consists of two ways. On the one hand, learners construct the meaning of present things to trace the given information; on the other hand, the original knowledge is not taken out unchangeably, but it will be constructed according to the variation of concrete situation. Learners' constructions are pluralistic, that is, each learner's constructions are different from each other's (Zhang Pengpeng, 2001).

It is not only a revolution of learning psychology, but also a leap of epistemology from behaviorism to constructivism. Behaviorism thinks that human understanding decides totally by the property of stimulus. The subject of understanding is passive, just as a mirror reflects an object. While constructivists think that man, as the subject of understanding, does not reflect reality unchangeably. In the process of understanding the individuals make choices and methods, and they also give special meaning of reality (jieminguojijiaoyubeikequanshu, 1990: 410). So understanding does not come from reality itself, but comes from the interaction between subjects and objects.

Constructivism stresses the subject's conscious activity, and objects to taking learners as passive acceptors. It considers teaching as a process that the students construct their knowledge actively. 
And the construction takes place by interaction with others. In teaching, teachers and companions are cooperators who construct knowledge. The companions have become constructive cooperators from the original competitors.

Based on constructivist theory, task-based language teaching takes the students as the main body of teaching and the active constructors of knowledge. The students are not the passive receivers of outside stimulus or the objects of knowledge inculcation any longer.

\section{The Second Language Acquisition Theory}

Krashen (1985) has suggested the notion of the affective filter. This is a representation of the way in which affective factors such as attitude, aniety, competitivesness, and other emotional responses can help or hinder language learning. The filter can be imagined as a sliding barrier which moves into place when a student is, for examole, tired, dispirted, tense, or angry, and which prevents the processing of input. A learner who has generally negative attitudes towards learning English will have a high affective filter and the task for the teacher will be substantial. The precise functioning of this filter is not explained, for example in relation to how it might affect the attention that students pay or do to various elements of input. However, the concept of the filter highlights the role of the teacherin creating benifitial conditions for language learning.

According to Krashen's second language acquisition theory, comprehensible input is the key to language acquisition. Krashen presents the case for comprehensible input in the form of the input hypothesis. He argues that for the second language acquisition to take place, the learner needs input that contains exemplars of the language forms which according to the natural order are due to be acquired next. Input must consist of ' $\mathrm{I}+1$ '. This will automatically occur when communication is successful. Krashen emphasizes that input does no need to be 'finely tuned' in the sense that it is linguistically adjusted t contain ' $\mathrm{I}+1$ '. It requires only rough thing, which is automatic if the focus is on successful communication. Krashen talks of the input 'casting a net' in order to make certain that it is of an optimal size, already acquired and guaranteeing that ' $\mathrm{I}+1$ ' is covered (Rod Ellis, 1986:157).

Swain suggests that output is important in several ways: (1) the learner may be 'pushed' to use alternative means where there is communication breakdown, in order to express a message precisely, coherently, and appropriately; (2) using the language may force the learner to move from semantic processing and (3) the learner has a chance to test out hypotheses about L2 (Rod Ellis, 1986:159).

From the second language acquisition theories, we know that input and output and interactions are necessary conditions for the second language acquisition. It is not only in natural linguistic situation, but it is true in classroom teaching. In our country English teaching and learning usually takes place in a normal. Therefore, input is always made in the artificial environment and is the major way for the learner to be exposed to the target language. How to make full use of the limited time and resources will determine the outcome of the language teaching. Teachers play a key role in how to turn more 'input' into 'output'. Through the interactions between the teacher to students or students to students, the quality and quantity of the linguistic input and output can be improved. Therefore, it can better improve the students' communicative competence and the abilities of solving problems in target language.

Using the research achievements obtained from the second language acquisition with the consideration of the actual conditions of vocational college English teaching, to set up teaching models that stress both input and output is all teachers' aim to work for.

\section{Group Dynamics Theory}

Kafka (see: Wang Tan, 2001:54), one of the founders of Gestalt School, once said, a group is a dynamic whole that the interdependence between the members can change. Levin, a colleague of Kafka explained the above opinion like this. Firstly, the nature of a group is the interdependence of the members that leads to the group becoming "a dynamic whole", in which any member's change will lead to the other member's change. Secondly, the inner nervous condition of the members can encourage the group to reach expected purpose (Johnson D.W., Johnson R.T. \& Hulubec E.J, 1993:5). Levin also did experimental research on group aims and individual aims. The result shows that in cooperative groups individuals have strong motives. They can encourage each other and 
make allowance for each other. The information communication between the individuals can go on fluently. The work efficiency of cooperative groups is obviously higher than that of those who are not cooperative groups (Johnson D.W., Johnson R.T. \& Hulubec E.J, 1993:5).

In America Johnson D.W. and Johnson R.T. developed the above theory into social interdependence theory. They did research on three kinds of aim structure, that is, cooperation, competition and go-it-alone. And they drew such a conclusion. Group cooperative structure should become the main organization form in class. Only this structure can reach the efficiency that promote the students' interaction and improve the teaching efficiency of the whole class.

From the viewpoint of group interaction, the core theory of task-based language teaching can be expressed in simple words. When all the people get together to work for the same purpose, they must depend on each other. The interdependence on each other provides interaction for individuals and make them, (A) encourage each other, willing to do whatever which promotes the group's success; (B) help each other, trying to make the group successful; (C) love and respect each other because people all like others to help themselves to reach the purpose. Hence group work has increased the connections of the group members to its most extent (Wang Tan, 2001:56-57).

In this part the author focuses on the theoretical bases of task-based language teaching and learning. In the light of the achievements obtained in the field and the actual English teaching situation in China vocational college, 3A (awareness, autonomy, authenticity) theory, group dynamics theory, the second language acquisition theory and social constructivist theory are taken as the theoretical bases of task-based language teaching and learning. With their help teachers in vocational college can employ such approach more consciously.

\section{Bibliography}

[1] Arnold, Jane. Affect in Language Learning. Beijing: Foreign Language Teaching and Research Press. 2000.

[2] Beretta, A. (1989) Attention to form or meaning?: Error treatment in the Bangalore Project. TESOL Quarterly, 23:283-303.Bottomley et al., 1994

[3] Breen, Michael P. and Littlejohn, Andrew. Classroom Decision-Making. Shanghai Foreign Language Educational Press. 2002

[4] Brumfit, C. J. and Johnson, K. The Communicative Approach to Language Teaching. Shanghai Foreign Language Educational Press. 2000

[5] Cohen, Andrew D. Strategies in Learning and Using a Second Language. Foreign Language Teaching and Research Press.2000

[6] Ellis, R. Understanding the Second Language Acquisition. Shanghai Foreign Language Education Press. 2000

[7] Gardner, David and Miller, Lindsay. Establishing Self-Access: from theory to practice. Shanghai Foreign Language Educational Press. 2002

[8] Harmer, Jeremy. How to Teach English. Foreign Language Teaching and Research Press. 2000

[9] Hedge, Tricia. Teaching and Learning in the Language Classroom. Shanghai Foreign Language Educational Press. 2002

[10] Krashen, S.D. (1981) Second language acquisition and second language learning. Oxford: Pergamon

[11] Kumaravadivelu, B. (1991) Language learning tasks: Teacher intention and learner interpretation. ELT Journal, 45:98-107.

[12] Larsen-Freeman, Diane and Long, Michael H. An Introduction to Second Language Acquisition Research. Foreign Language Teaching and Research Press. 2000

[13] Leech, G. and J. Svartvik (1975) A communicative grammar of English. London: Longman.

[14] Lightbown, Patsy M. and Spada Nina. How Languages Are Learned. Shanghai Foreign Language Educational Press. 2002

[15] Long, M.H. and Crookes, G. (1992) Three approaches to task-based syllabus design. TESOL Quarterly 26(1):27-56. 
[16] Marsland, Bruce. Lessons from Nothing. People’s Educational Press. 2000

[17] Nunan, David. Designing Tasks for the Communicative Classroom. People's Educational Press. 2000

[18] Nunan, David. The Learner-Centered Curriculum: A study in second language teaching. Shanghai Foreign Language Educational Press. 2001

[19] Richards, Jack C. and Rodgers, Theodore S. Approaches and Methods in Language Teaching. Foreign Language Teaching and Research Press.2000

[20] Rivers, Wilga M. Interactive Language Teaching. People’s Educational Press. 2000

[21] Wilkins, D. A. Notional syllabus. Oxford University Press. 1983.

[22] Candlin, C. N. Towards task-based learning. In Candlin, C. N. \& D. Murphy (eds.), (1987). Lancaster Practical Papers in English Language Education; Vol. 7. Language learning tasks (pp. 5-22). Englewood Cliffs, NJ: Prentice Hall. 1987.

[23] Finch, A. E. The Task-based Classroom in Practice. Solmae Review on Language and Literature Vol. 11, pp 179-98. ANU Press: Andong National University. 1999. 